\title{
SKRINING DAN IDENTIFIKASI MIKROBA LIGNINOLITIK PADA PENGOMPOSAN ALAMI TANDAN KOSONG KELAPA SAWIT
}

\author{
Screening and Identification of Ligninolytic Microbes \\ in the Natural Decomposition of Oil Palm Empty Fruit Bunch
}

\author{
Bedah Rupaedah*, Devit Purwoko, Anna Saffarida, Teuku Tajuddin, Abdul Wahid, \\ Mahmud Sugianto, Imam Suja'i, Agus Suyono \\ Balai Bioteknologi, Badan Pengkajian dan Penerapan Teknologi \\ Gedung 630, Kawasan Puspiptek, Tangerang Selatan, Banten \\ *Email: bedah.rupaedah@bppt.go.id
}

\begin{abstract}
OPEFB (oil palm empty fruit bunch) could potentially be utilized as organic fertilizer or animal feed through composting. Information on microorganisms that play important roles in the natural decomposition of OPEFB is to date not much known yet. This research was aimed to obtain and, subsequently, to molecularly identify lignin-degrading microbial isolates responsible for naturally decomposing OPEFB in the Oil Plant Plantation and Palm Oil Refinery Plant, PTPN VIII Cikasungka, Bogor. Screening for active lignin-degrading isolates was carried out on 17 naturally decomposing OPEFB samples. A total of 19 isolates of fungi and 80 isolates of bacteria were obtained. Ligninolytic activity was measured by Sundman and Nase testing methods. Ligninolytic activity was found on 13 fungal isolates and 15 bacterial isolates. The active isolates were subsequently identified molecularly based on ITS sequence in the ribosome DNA area for fungi and in 16S rRNA genes for bacteria. The results showed that the lignin-degrading microorganisms obtained consisted of 5 bacterial isolates from the genus Bacillus and 3 fungal isolates from the genus Rhizopus and Aspergillus.
\end{abstract}

Keywords: composting, lignin, microbes, OPEFB, $16 S$ rRNA

\begin{abstract}
ABSTRAK
TKKS (tandan kosong kelapa sawit) berpotensi dimanfaatkan sebagai pupuk organik atau pakan ternak dengan cara pengomposan. Informasi mikroba yang berperan dalam pengomposan alami TKKS hingga saat ini belum banyak diketahui. Penelitian ini bertujuan mendapatkan isolat mikroba pendegradasi lignin dalam pengomposan alami TKKS asal Perkebunan dan Pabrik Pemerasan Kelapa Sawit, PTPN VIII Cikasungka, Bogor, serta mengidentifikasi mikroba tersebut secara molekuler. Skrining mikroba aktif pendegradasi lignin dilakukan terhadap 17 sampel TKKS yang sudah lapuk secara alami. Sebanyak 19 isolat jamur dan 80 isolat bakteri telah dihasilkan. Aktivitas ligninolitik diukur dengan metode pengujian Sundman dan Nase. Isolat jamur yang memiliki aktivitas ligninolitik sebanyak 13 isolat, sedangkan bakteri sebanyak 15 isolat. Isolat-isolat aktif tersebut selanjutnya diidentifikasi secara molekuler berdasarkan pada sekuen ITS di daerah DNA ribosom untuk jamur dan menggunakan gen 16S rRNA untuk bakteri. Hasil menunjukkan bahwa 5 isolat bakteri yang memiliki kemampuan mendegradasi lignin berasal dari genus Bacillus, sedangkan 3 isolat jamur pendegradasi lignin berasal dari genus Rhizopus dan Aspergillus
\end{abstract}

Kata Kunci: lignin, mikroba, pengomposan, TKKS, 16S rRNA 


\section{PENDAHULUAN}

Indonesia merupakan salah satu penghasil komoditas kelapa sawit terbesar di dunia. Produksi CPO Indonesia tahun 2017 mencapai 2,7 juta Ton (BPS 2017). Setiap pabrik kelapa sawit (PKS) dengan kapasitas 60 ton/jam dapat mengolah TBS hingga 1000 ton/hari (Darnoko dan Sutarta, 2006). 23\% dari tandan buah segar (TBS) merupakan tandan kosong kelapa sawit (TTKS) yang menjadi limbah dan menjadi permasalahan bagi PKS karena membutuhkan biaya dan waktu dalam penanganannya. Sebagai limbah, tandan kosong kelapa sawit (TTKS) berpotensi untuk dimanfaatkan kembali, salah satunya dengan cara pengomposan menjadi pupuk organik. Pembuatan pupuk organik (kompos) memerlukan mikroba pengompos agar proses pengomposan berjalan lebih cepat dan lebih baik.

Pada penelitian proses pengomposan biomassa tanaman, termasuk TKKS, yang selama ini menjadi perhatian adalah bagaimana memahami beberapa bagian proses degradasi oleh mikroba yaitu degradasi selulosa dan hemiselulosa menghasilkan gula fermentasi melalui proses hidrolisis. Bagian proses degradasi yang juga sangat penting untuk dipahami adalah dekomposisi lignin (Khitrin et al. 2012). Kandungan lignin TKKS mencapai 27,7\% (Rosli et al. 2017) yang harus dihilangkan sebelum terjadi proses degradasi selulosa dan hemiselulosa.

Mikroba yang memiliki aktivitas lignoselulolitik diketahui merupakan mikroba dari golongan bakteri (Widiastuti et al. 2017; $\mathrm{Xu}$ et al. 2018), aktinomisetes dan jamur (Choirunnisa et al. 2017). Mikroba yang paling aktif dalam mendegradasi lignin adalah jamur (Prenafeta-Boldú et al. 2018), seperti jamur yang termasuk ke dalam famili jamur pelapuk putih (Ruiz-Dueñas dan Martínez 2009; Jurado et al. 2011; Rodríguez-Couto 2017) dan jamur pelapuk coklat (Lee et al. 2008; Zhang et al. 2016; Riley et al. 2018) yang mampu mendekomposisi kayu. Beberapa jenis bakteri yang diketahui mampu mendegradasi lignin dalam TKKS, di antaranya adalah Burkholderia sp (Yang et al. 2017), Bacillus, Exiguobacterium, Desemzia, Planococcus, Thermobacillus xylanilyticus, Brachybacterium

faecium,
Cellulosimicrobium cellulans, Cellulomonas sp. dan Thermobifida fusca (Zainudin et al. 2014).

Berdasarkan hasil penelitian yang dilakukan Liew et al. (2009) melalui analisis terhadap gen PCR-amplified 16S rRNA, terdapat keanekaragaman jenis bakteri yang terdapat dalam kompos yang dibuat dari TKKS, di antaranya adalah Bacillus circulans, Bacillus thermoamylovorans, Bacillus thermoamylovorans, Bacillus coagulans, Beta-Proteobacteria Variovoraxkoreensis, Curvibacter delicates, Pelomonas saccharophila, Gamma-Proteobacteria methylomicrobium, Aspromonas composti, Lysobactergummosus, Thermomonas haemolytica, dan Delta-Proteobacteria Nannocystis.

Tujuan dari penelitian ini adalah untuk mendapatkan isolat mikroba yang mampu mendegradasi lignin dalam pengomposan tandan kosong kelapa sawit (TKKS) yang diperoleh dari Perkebunan dan Pabrik Pemerasan Kelapa Sawit, PTPN VIII Cikasungka, Bogor, serta mengidentifikasi mikroba tersebut secara molekuler.

\section{BAHAN DAN METODE}

\section{Tempat dan waktu penelitian}

Penelitian ini dilaksanakan di Laboratorium Agromikrobiologi dan Laboratorium Teknologi Gen, Balai Bioteknologi BPPT, Puspiptek, mulai bulan Juli hingga November 2018.

\section{Bahan}

TKKS yang sudah lapuk secara alami diperoleh dari Perkebunan dan Pabrik Pemerasan Kelapa Sawit, PTPN VIII Cikasungka, Bogor (Gambar 1). Sampel TKKS yang diambil adalah hasil penumpukan TKKS di lokasi Perkebunan Kelapa Sawit dari tahun 2016-2018 dan di sekitar Pabrik Pemerasan Sawit dari tahun 2016-2018.

\section{Skrining mikroba pendegradasi lignin}

Skrining dimulai dengan isolasi jamur menggunakan media PDA (potato dextrose agar) dan untuk isolasi bakteri menggunakan media NA (nutrient agar). Isolat-isolat jamur dan bakteri yang diperoleh diuji aktivitasnya dalam mendegradasi senyawa lignin, yang merupakan komponen penting dalam TKKS yang harus dihancurkan untuk memperoleh 
kompos TKKS yang memenuhi kriteria sebagai kompos siap pakai.

Pengujian aktivitas ligninolitik dilakukan dengan menggunakan metode Sundman dan Nase (Lopez et al. 2006). Satu $\mathrm{cm}$ jamur atau 1 ose bakteri diinokulasikan pada media dengan komposisi sebagai berikut: glukosa $5 \mathrm{~g}$, amonium tartarat $5 \mathrm{~g}$, malt ekstrak $1 \mathrm{~g}$, $\mathrm{MgSO}_{4} \cdot 7 \mathrm{H}_{2} \mathrm{O} 0,5 \mathrm{~g}, \mathrm{CaCl}_{2} \cdot 2 \mathrm{H}_{2} \mathrm{O} 0,01 \mathrm{~g}$, tiamin $0,001 \mathrm{~g}, \mathrm{NaCl} 0,1 \mathrm{~g}, \mathrm{FeCl}_{3} 0,01 \mathrm{~g}$, alkali kraft lignin $0,01 \mathrm{~g}$, agar $20 \mathrm{~g}$. Setelah 10 hari, kultur diwarnai dengan pewarna yang berisi satu bagian $\mathrm{FeCl}_{3} \cdot 6 \mathrm{H}_{2} \mathrm{O} 1 \%$ dan satu bagian $\mathrm{K}_{3}\left[\mathrm{Fe}(\mathrm{CN})_{6}\right] \quad 1 \%$. Pengujian dilakukan pada temperatur kamar $\left(28^{\circ} \mathrm{C}\right)$. Pereaksi tersebut membuat media menjadi berwarna hijau. Adanya zona bening di sekitar koloni mikroba mengindikasikan adanya aktivitas degradasi lignin oleh mikroba.

\section{Isolasi DNA isolat bakteri dan jamur}

Isolasi DNA genom dari kultur bakteri dan jamur dilakukan dengan menggunakan Kit InstaGene ${ }^{\mathrm{TM}}$ Matrix dan PrepMan ${ }^{\mathrm{TM}}$ Ultra yang telah dimodifikasi.

\section{Amplifikasi 16S rDNA dan ITS}

Berdasarkan hasil uji isolat bakteri dan jamur yang terseleksi, selanjutnya isolat bakteri dan jamur tersebut dipilih untuk analisis sekuen gen 16S rDNA dan ITS. DNA isolat-isolat bakteri dan jamur digunakan sebagai template pada proses PCR (Polimerase Chain Reaction). Gen 16S rDNA diamplifikasi menggunakan primer foward 8F (5'AGAGTTTGATCCTGGCTCAG-3') dan primer reverse 1492R (5'GGTTACCTTACCTTGTTACGACTT-3'), sedangkan gen ITS diamplifikasi menggunakan primer foward ITS 1 (5' -TCC GTA GGT GAA CCT GCG G- 3') dan primer reverse ITS 4 (5'TCCTCCGCTTATTGATATGC-3'). Konsentrasi primer yang digunakan adalah $10 \mathrm{pmol} / \mu \mathrm{L}$. Komposisi PCR yang digunakan adalah 12,5 $\mu \mathrm{L}$ GoTaq ${ }^{\circledR}$ Green Master Mix, $2 \mu \mathrm{L}$ primer foward dan reverse, template DNA $50 \mathrm{ng} / \mu \mathrm{L}$, dan $6,5 \mu \mathrm{L} \mathrm{dH}_{2} \mathrm{O}$. Siklus PCR berlangsung pada kondisi denaturasi awal (pre-denaturasi) $95^{\circ} \mathrm{C}$ selama 5 menit dan proses selanjutnya sebanyak 30 siklus yang terdiri dari denaturasi $\left(94^{\circ} \mathrm{C}\right.$ selama 45 detik), annealing $\left(52^{\circ} \mathrm{C}\right.$ selama 1 menit), dan elongasi $\left(72^{\circ} \mathrm{C}\right.$ selama 1 menit). Setelah akhir siklus, polimerisasi dilanjutkan pada suhu $72^{\circ} \mathrm{C}$ selama 5 menit. Hasil PCR kemudian dianalisis dengan elektroforesis pada gel agarose $1 \%$. Visualisasi dilakukan dengan sinar UV pada UV-transiluminator. Fragmen DNA yang telah dipurifikasi digunakan sebagai template dalam analisis sekuen.
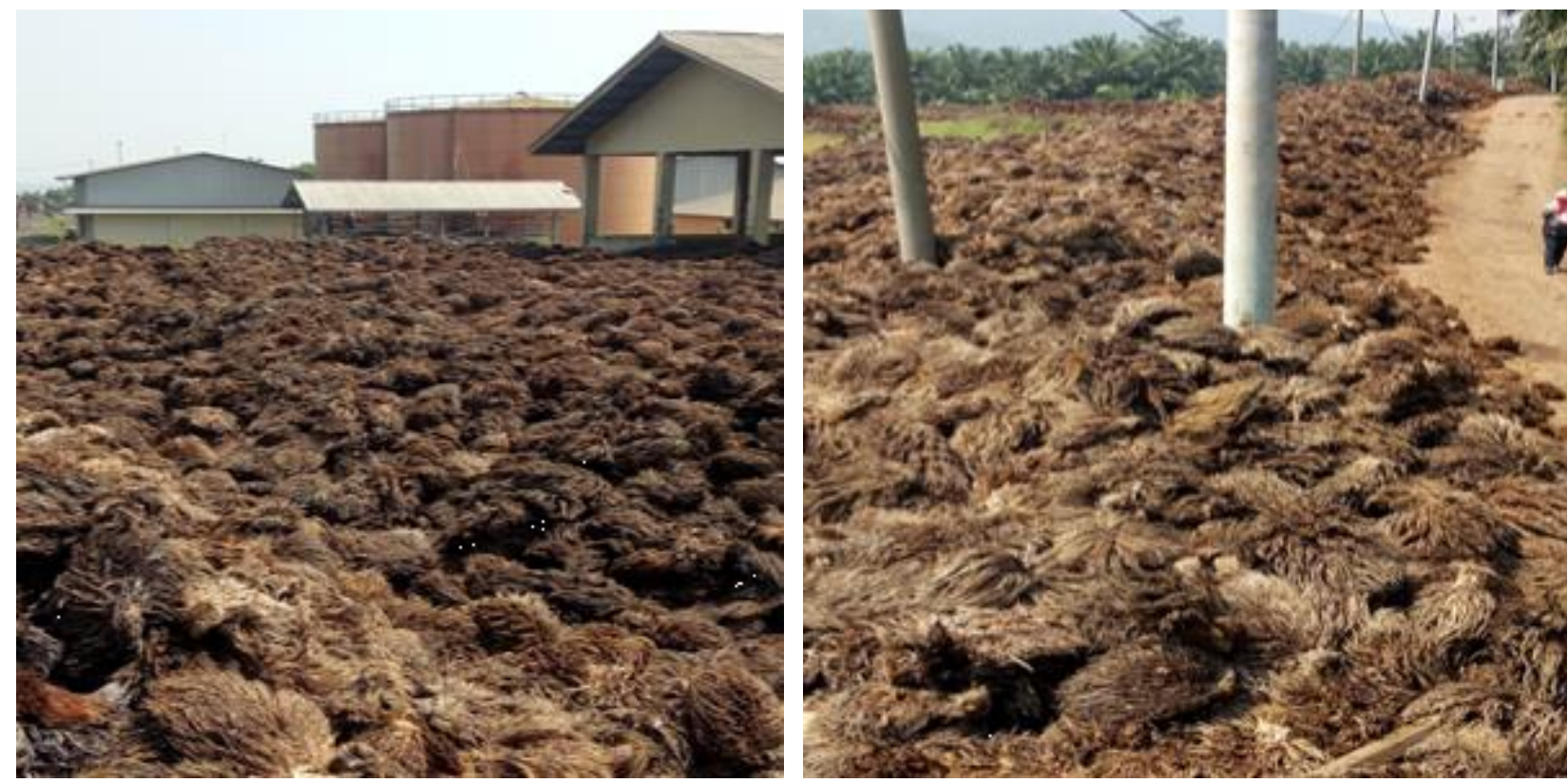

Gambar 1. Tumpukan TKKS di Pabrik Pemerasan PTPN VIII Kebun Cikasungka Bogor 
Tabel 1. Lima belas isolat bakteri yang memiliki aktivitas ligninolitik

\begin{tabular}{|c|c|c|c|c|c|c|}
\hline \multirow{2}{*}{ No. } & \multirow{2}{*}{ Kode sampel } & \multicolumn{4}{|c|}{ Ciri koloni bakteri } & \multirow{2}{*}{$\begin{array}{l}\text { Aktivitas } \\
\text { ligninolitik }\end{array}$} \\
\hline & & Bentuk & Tepi & Elevasi & Warna & \\
\hline 1 & 2SPSB2016(1)6 & Bulat & Halus & Timbul & Putih & +++ \\
\hline 2 & 3SPSB2018(1)1 & Bulat & Halus & Timbul & Putih & ++ \\
\hline 3 & 3SPSB2018(1)3 & Bulat & Bergelombang & Cembung & Putih kekuningan & ++ \\
\hline 4 & 3SPSB2018(1)5 & Bulat tidak rata & Berbulu & Cembung & Putih mengkilat & +++ \\
\hline 5 & 4SPSA2017(1)6 & Bulat & Bercabang & Timbul & Putih kekuningan & ++ \\
\hline 6 & 5SPSB2016(2)2 & Konsentris & Bercabang & Cembung & Putih kekuningan & + \\
\hline 7 & 5SPSB2016(2)4 & Bulat & Halus & Timbul & Putih & +++ \\
\hline 8 & 6SPSA2017(1)2 & Bulat tidak rata & Bergelombang & Datar & Putih & ++ \\
\hline 9 & 7SPSB2017(1)4 & Bulat & Halus & Cembung & Putih mengkilat & + \\
\hline 10 & 8SPSA2016(2)4 & Bulat tidak rata & Bersilia & Datar & Putih susu & +++ \\
\hline 11 & 1TKKSA (1)6 & Bulat tidak rata & Bercabang & Timbul & Putih & + \\
\hline 12 & $3 T K K S C(1 b l) 3$ & Bulat & Halus & Timbul & Putih & ++ \\
\hline 13 & 4TKKSTRA(2bl)1 & Bulat & Halus & Cembung & Putih mengkilat & +++ \\
\hline 14 & 7TKKSB(3bl)4 & Bulat & Halus & Timbul & Putih & +++ \\
\hline 15 & 8TKKSA $(3 \mathrm{bl}) 3$ & Bulat tidak rata & Bergelombang & Cembung & Merah tua & +++ \\
\hline
\end{tabular}

Tabel 2. Tiga belas isolat jamur yang memiliki aktivitas ligninolitik

\begin{tabular}{clcc}
\hline No. & Kode isolat & Ciri morfologi jamur & $\begin{array}{c}\text { Aktivitas } \\
\text { ligninolitik }\end{array}$ \\
\hline 1 & 3SPSB(1m) 1J & Miselia hijau, bagian tengah melingkar, spora hijau tua & ++ \\
2 & 4SPSA2016(2)1J & Miselia putih, padat & + \\
3 & 4SPSA2016(2)2J & Miselia putih, spora putih & ++ \\
4 & 1TKKSA(1m)1J & Miselia putih, spora hitam & + \\
5 & 1TKKSA(1m)2J & Miselia coklat muda, sopra coklat & +++ \\
6 & 2TKKSB(1m)3J & Miselia putih & + \\
7 & 2TKKSB(1m)4J & Miselia hitam, spora hitam & ++ \\
8 & 3TKKSC(1bl)1J & Miselia putih, spora hitam & ++ \\
9 & 3TKKSC(1bl)2J & Miselia putih, berserabut tebal & ++ \\
10 & 3TKKSC(1bl)4J & Miselia putih, spora hijau & ++ \\
11 & 4TKKSTRA(2bl)2J & Miselia putih kehijauan & +++ \\
13 & 8TKKSA(3bl)4J & Miselia putih, spora hijau & + \\
\hline
\end{tabular}

\section{Sekuensing gen 16S rDNA dan ITS}

Hasil PCR gen 16S rDNA dan ITS diberi label menggunakan Big Dye Terminator Reaction Mixture Sequencing Kit dari Perkin Elmer. Sekuensing dilakukan untuk menentukan urutan nukleotida pada fragmen DNA yang terdeteksi dari hasil visualisasi DNA yang teramplifikasi dalam proses PCR menggunakan mesin autosequencing. Proses sekuensing dilakukan dengan mengirim sampel ke First Base Pte. Malaysia.

\section{Nomenklatur isolat bakteri dan jamur terpilih}

Nomenklatur isolat bakteri dan jamur terpilih dilakukan berdasarkan hasil pembacaan urutan basa gen 16S rDNA dan ITS. Hasil sekuen parsial gen 16S rDNA dan ITS melalui software BLAST dibandingkan dengan data gen serupa pada Gen Bank NCBI (National Center for Biotechnology Information) dalam situs www.ncbi.nml.nih.gov. Selanjutnya penamaan isolat bakteri dilakukan dengan analisis filogenetik melalui pohon filogenetik 
menggunakan program ClustalW (SOP Laboratorium Teknologi Gen Balai Bioteknologi BPPT).

\section{HASIL DAN PEMBAHASAN}

\section{Hasil isolasi dan pengujian aktivitas ligninolitik}

Skrining mikroba yang aktif mendegradasi lignin dilakukan terhadap 17 sampel TKKS yang sudah lapuk secara alami pada rentang antara tahun 2015 hingga 2018 di PTPN VIII Kebun Cikasungka Bogor. Sebanyak 19 isolat jamur dan 80 isolat bakteri telah berhasil diisolasi (Gambar 2). Aktivitas ligninolitik diuji dengan menggunakan metode pengujian Sundman dan Nase (Lopez et al. 2006). Isolat bakteri yang memiliki aktivitas ligninolitik sebanyak 15 isolat (Tabel 1), sedangkan jamur sebanyak 13 isolat (Tabel 2).
Senyawa lignin termasuk senyawa kimia yang sulit terdegradasi secara alami, sehingga untuk menghancurkannya memerlukan waktu yang lama. Selulosa dan hemiselulosa bersatu dengan lignin secara terintegritasi sehingga menyulitkan dalam degradasi lignoselulosa oleh enzim (Dhillon dan Kaur 2016). Dekomposisi lignin adalah reaksi yang sangat lambat (Deublein dan Steinhauser 2011). TKKS memiliki kandungan lignin sehingga lambat terdekomposisi di alam. Dengan penggunaan inokulum mikroba dalam dekomposisi TKKS menjadi pilihan dalam mempercepat proses pengomposan. Dalam penelitian ini diperlukan waktu minimal 10 hari untuk terbentuknya zona bening dengan diameter yang tidak terlalu lebar (Gambar 3). Hal tersebut dapat disebabkan karena secara morfologi lignin merupakan senyawa amorf

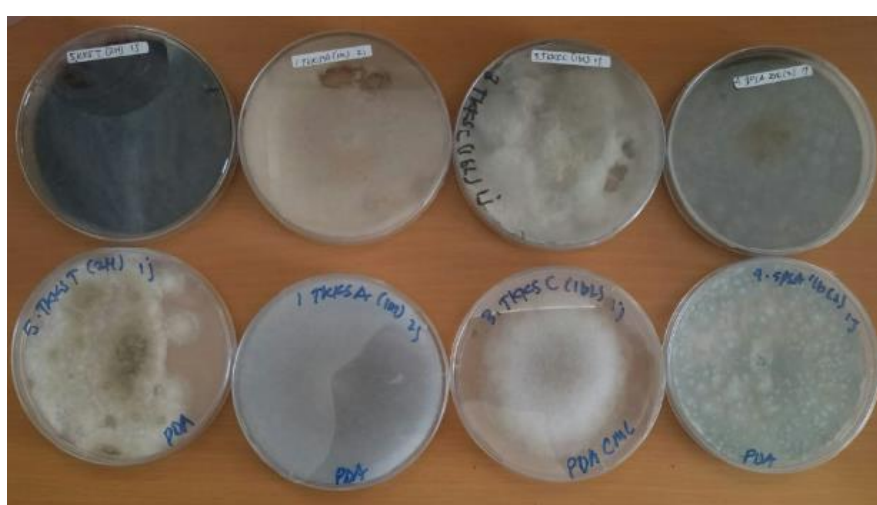

A

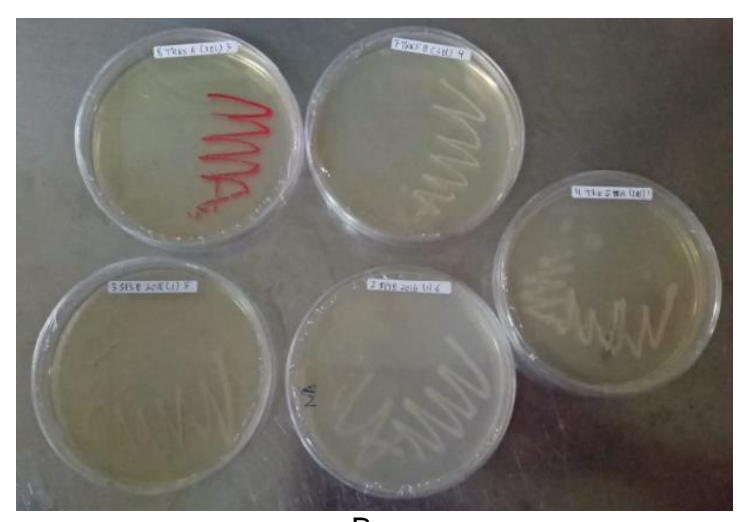

B

Gambar 2. Isolat -isolat jamur (A), isolat-isolat bakteri $(B)$ yang efektif mendegradasi lignin
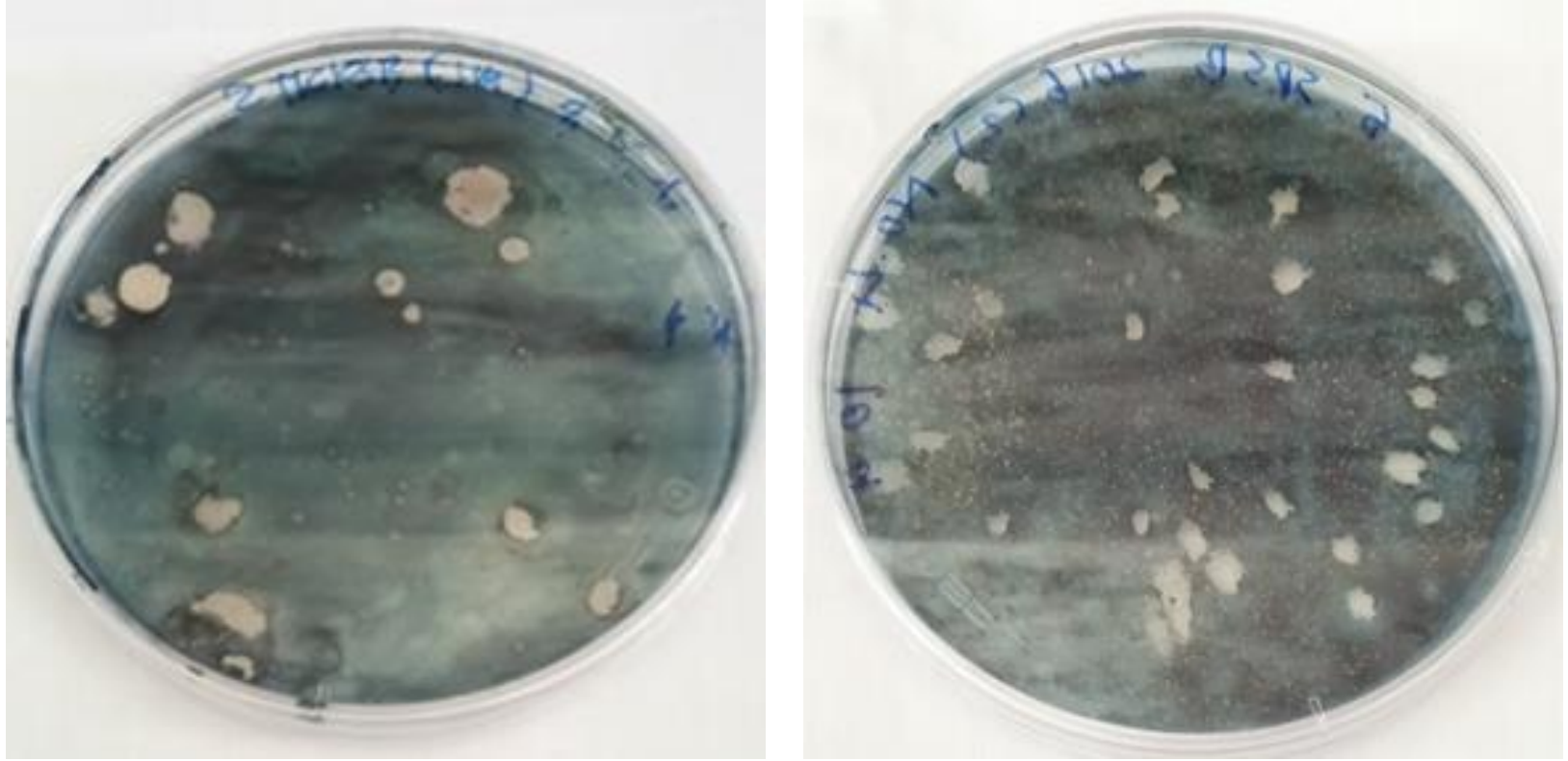

Gambar 3. Bakteri dengan aktivitas ligninolitik 
yang terdapat dalam lamela tengah majemuk maupun dalam dinding sekunder, sehingga memperkuat dinding sel (Cesarino et al. 2012). Dinding sel tersusun oleh suatu rangka molekul selulosa dan lignin. Kedua bagian ini merupakan satu kesatuan erat, yang menyebabkan dinding sel menjadi sangat kuat menyerupai beton bertulang besi (Cesarino et al. 2012).

Enzim ekstraseluler LiP (lignin peroxidase) dan MnP (manganese peroxidase) memiliki peranan yang sangat penting dalam proses biodelignifikasi. Enzim LiP memiliki kemampuan mengkatalis beberapa reaksi oksidasi antara lain pemecahan ikatan $\mathrm{Ca}-\mathrm{CB}$ rantai samping propil non fenolik komponen aromatik lignin, oksidasi benzil alkohol, oksidasi fenol, hidroksilasi grup benzylic methylene dan pemecahan cincin aromatic komponen non fenolik senyawa lignin (Xu et al. 2013; Falade et al. 2017; Datta et al. 2017).

\section{Hasil identifikasi secara molekuler}

Identifikasi secara molekuler dilakukan terhadap 5 isolat bakteri (4TKKSTRA(2bl)1, 7TKKSTRA(3 bl)4, 3 SPSB 2018(1)5, 2 SPSB2016(1)6, dan 5SPSB2016(2)4) dan 3 isolat jamur (3TKKSC(1bl) $1 \mathrm{j}$, 4SPSA2016(2)1j, dan 5TKKST $(2 \mathrm{H}) 1 \mathrm{j})$ yang memiliki aktivitas terbaik dalam mendegradasi lignin. Proses ini diawali dengan ekstraksi DNA menggunakan Kit InstaGene $^{\mathrm{TM}}$ Matrix dan PrepMan ${ }^{\mathrm{TM}}$ Ultra
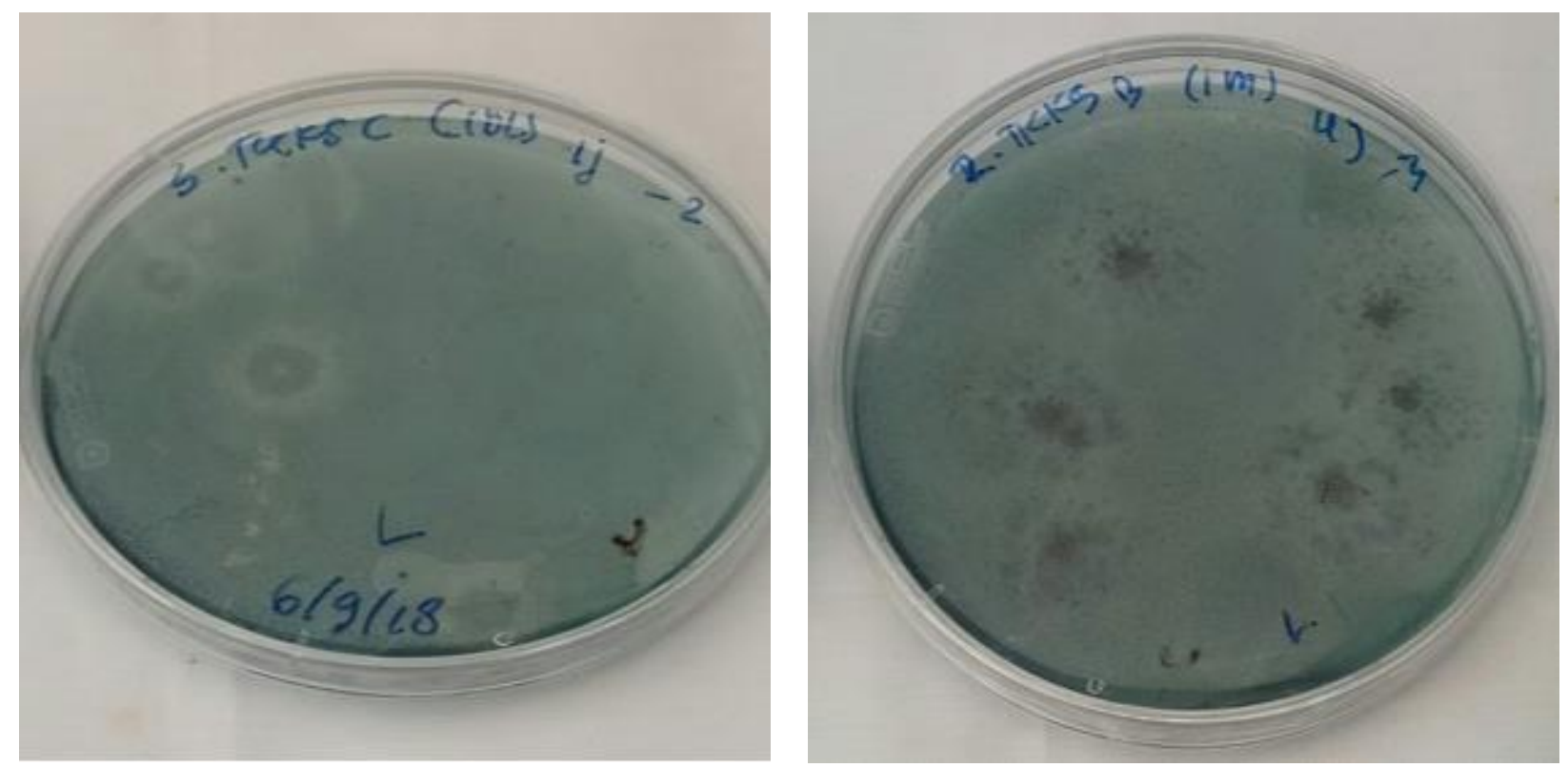

yang dilanjutkan dengan amplifikasi PCR menggunakan primer untuk gen 16S rRNA 8 $\mathrm{F}$ (forward) dan 1492R (reverse) yang dapat mengamplifikasi gen 16S rRNA sepanjang $1.484 \mathrm{bp}$ pada isolat bakteri serta primer untuk gen ITS yaitu ITS1 (forward) dan ITS4 (reverse). Produk PCR yang merupakan DNA teramplifikasi dielektroforesis menggunakan gel agarose $1 \%$ sebagai uji kualitatif.

Hasil elektroforesis menunjukan fragmen DNA dari isolat bakteri dengan kode 4TKKSTRA(2bl)1, 7TKKSTRA(3bl)4, 3SPSB2018(1)5, 2SPSB2016(1)6, dan 5SPSB2016(2)4 berturut-turut diperoleh sekuen 16S rDNA sepanjang 1398 bp, 1421 bp, 1408 bp, 1407 bp, dan 1425 bp. Sedangkan pada isolat jamur dengan kode 3TKKSC(1bl)1j, 4SPSA2016(2)1j, dan $5 T K K S T(2 \mathrm{H}) 1 \mathrm{j}$ berturut-turut diperoleh sekuen ITS sepanjang 697 bp, 605 bp, dan $611 \mathrm{bp}$.

Sekuensing dilakukan dengan mengirim produk PCR DNA ke First Base Pte. Malaysia. Sekuen-sekuen ini selanjutnya dibandingkan dengan sekuen serupa yang terdaftar dalam Bank Gen untuk mengetahui afiliasi filogenetik melalui program BLAST (Basic Local Alignment Search Tool) yang diakses secara online melalui website NCBI (http://blast.ncbi.nlm.nih.gov/Blast.cgi). Analisis filogenetik dilakukan menggunakan program ClustalW (SOP Laboratorium Teknologi Gen Balai Bioteknologi BPPT).

Gambar 4. Jamur dengan aktivitas ligninolitik 
Hasil analisis filogenetik isolat bakteri dan jamur disajikan pada Gambar 5A dan 5B. Berdasarkan Gambar 5A tampak bahwa isolat dengan kode 4TKKSTRA(2bl)1, 7TKKSTRA(3bl)4, 3 SPSB 2018 (1) 5, 2 SPS B 2016 (1) 6, dan 5 SPSB 2016 (2) 4 memiliki kemiripan berturut-turut dengan Bacillus subtilis strain BRM043928 (MH305345.1), Bacillus tequilensis strain 52-LR1-2 (MF077125.1), Bacillus paramycoides strain SKB12 (MH900215.1), Bacillus cereus strain PgBE247 (MH144317.1), dan Bacillus subtilis strain LE24 (MG980567.1). Berdasarkan nilai similaritas 16S rDNA-nya diketahui bahwa isolat dengan kode 4 TKKS TRA (2bl) 1, 7 TKKS TRA (3 bl) 4, 3 SPSB 2018 (1) 5, 2 SPS B 2016 (1) 6, dan 5 SPSB 2016 (2) 4 mempunyai nilai similaritas berturut-turut dengan Bacillus subtilis strain BRM043928 dengan similarity $100 \%$, Bacillus tequilensis strain 52-LR1-2 dengan similarity 99\% (hasil blast tgl 16/10/2018, Bacillus paramycoides strain SKB12 dengan similarity 100\% (hasil blast tgl 16/10/2018, Bacillus cereus strain PgBE247 dengan similarity $100 \%$, dan Bacillus subtilis strain LE24 dengan similarity $99 \%$. Hasil tersebut sesuai dengan beberapa penelitian yang menyatakan bahwa Bacillus telah berhasil diisolasi dan memiliki aktivitas dekomposisi lignin (Bandounas et al. 2011; Huang et al. 2013; Chang et al. 2014; Woo et al. 2014; Falade et al. 2017).

Analisis filogenetik isolat jamur pada Gambar 5B tampak bahwa isolat dengan kode 3TKKSC(1bl)1j, 4SPSA2016(2)1j, dan $5 \operatorname{TKKST}(2 \mathrm{H}) 1 \mathrm{j}$ memiliki kemiripan berturut-

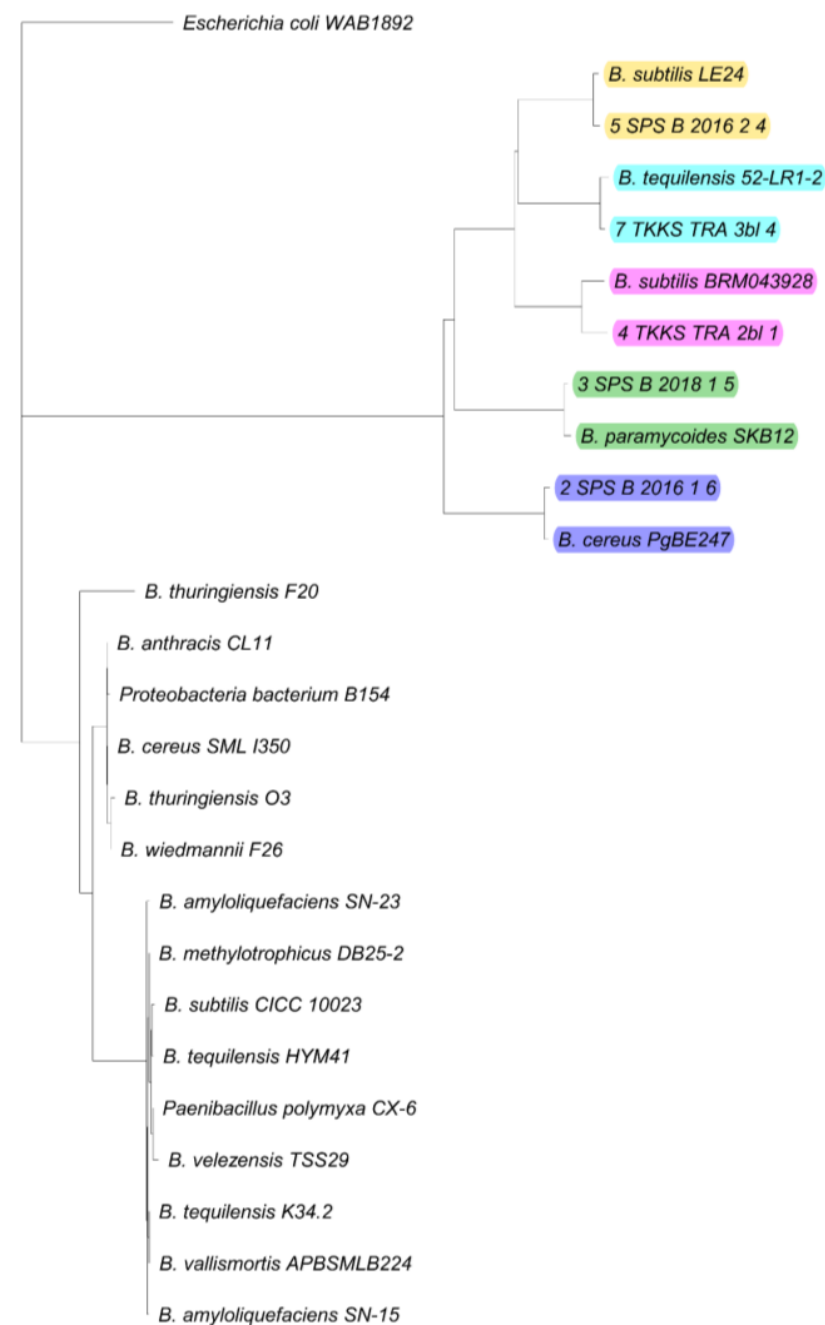

A

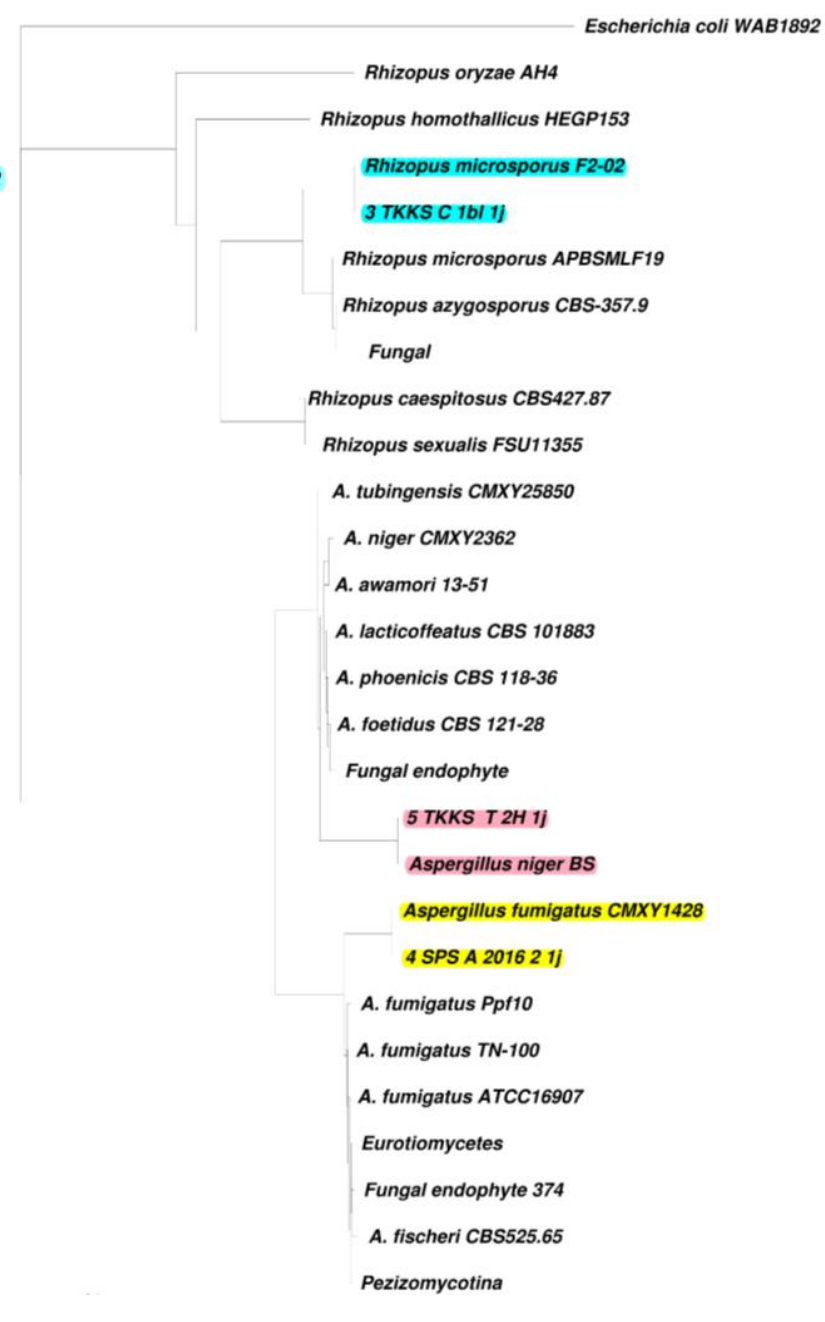

B

Gambar 5. A). Pohon filogenetik hubungan kekerabatan antara isolat bakteri dengan anggota genus Bacillus

B). Pohon filogenetik hubungan kekerabatan antara isolat jamur dengan anggota genus Rhizopus dan Aspergillus 
turut dengan Rhizopus microsporus isolat F202 (JN561253.1), Aspergillus fumigatus strain CMXY14287 (MG991614.1), dan Aspergillus niger isolat BS (MH050407.1). Berdasarkan nilai similaritas ITS-nya diketahui bahwa isolat dengan kode $3 T K K S C(1 \mathrm{bl}) 1 \mathrm{j}$, 4SPSA2016(2)1j, dan 5TKKST(2H) $1 \mathrm{j}$ mempunyai nilai similaritas berturut-turut dengan Rhizopus microsporus isolat F2-02 dengan similarity $100 \%$, Aspergillus fumigatus strain CMXY14287 similarity 99\%, Aspergillus niger isolat BS similarity $99 \%$. Hal tersebut sesuai dengan hasil penelitian Valencia et al. (2017) yang menyatakan bahwa Aspergillus niger merupakan salah satu dari banyak jamur yang memiliki kemampuan mendegradasi lignin.

Informasi isolat dengan aktivitas ligninolitik pada penelitian ini dapat dimanfaatkan untuk pengembangan konsorsium mikroba pendegradasi lignin. Melalui pemanfaatan konsorsium mikroba pendegradasi lignin diharapkan dapat membantu penanganan limbah TKKS.

\section{KESIMPULAN}

Sebanyak 19 isolat jamur dan 80 isolat bakteri telah berhasil diisolasi dari sampel limbah TTKS. Sebanyak 15 isolat bakteri dan 13 isolat jamur yang memiliki kemampuan mendegradasi lignin secara in vitro telah diperoleh. Lima isolat bakteri yang memiliki kemampuan mendegradasi lignin termasuk ke dalam genus Bacillus, yaitu Bacillus subtilis strain BRM043928 (MH305345.1), Bacillus tequilensis strain 52-LR1-2 (MF077125.1), Bacillus paramycoides strain SKB12 (MH900215.1), Bacillus cereus strain PgBE247 (MH144317.1), dan Bacillus subtilis strain LE24 (MG980567.1). Sedangkan 3 isolat jamur yang mampu mendegradasi lignin terdiri dari Rhizopus microsporus isolat F2-02 (JN561253.1), Aspergillus fumigatus strain CMXY14287 (MG991614.1), dan Aspergillus niger isolat BS (MH050407.1).

\section{UCAPAN TERIMA KASIH}

Ucapan terima kasih disampaikan kepada Kementerian Riset, Teknologi dan Pendidikan Tinggi atas pendanaan penelitian ini melalui Program Insentif Sistem Inovasi Nasional (Insinas) tahun 2018.

\section{DAFTAR PUSTAKA}

Bandounas L, Wierckx NJP, de Winde JH, Ruijssenaars HJ (2011) Isolation and characterization of novel bacterial strains exhibiting ligninolytic potential . BMC Biotechnol 11:94. doi: 10.1186/1472-6750-11-94

Cesarino I, Araújo $P$, Pereira $A$, Júnior $D$, Mazzafera P (2012) An overview of lignin metabolism and its effect on biomass recalcitrance. Braz $\mathrm{J}$ Bot 35:303-311. doi: 10.1590/S010084042012000400003

Chang YC, Choi DB, Takamizawa K, Kikuchi S (2014) Isolation of Bacillus sp. strain capable of decomposing alkali lignin and their application in combination with lactic acid bacteria for enhancing cellulase performance. Bioresour Technol 152:429-436. doi:10.1016/j.biortech.2013.11.032

Choirunnisa, Zul D, Pratiwi NW (2017) Formulasi mikroorganisme lignoselulolitik asal tanah gambut desa rimbo panjang, kampar sebagai bioaktivator bentuk padat. J Riau Biologia 2:90 - 99

Datta R, Kelkar A, Baraniya D, Molaei A, Moulick A, Meena RS, Formanek P (2017) Enzymatic degradation of lignin in soil: A review. Sustainability 9:1163. doi: $10.3390 /$ su9071163

Deublein D, Steinhauser A (2011) Biogas from waste and renewable resources: An introduction. John Wiley \& Sons, Weinheim

Dhillon GS, Kaur S (2016) Agro-industrial wastes as feedstock for enzyme production: Apply and exploit the emerging and valuable use options of waste biomass. Academic Press, London.

doi: 10.1002/9783527632794.ch37

Darnoko, Sutarta AS (2006) Pabrik kompos di pabrik sawit. Tabloid Sinar Tani, Jakarta

Falade AO, Eyisi OAL, Mabinya LV, Nwodo UU, Okoh Al (2017) Peroxidase production and ligninolytic potentials of fresh water bacteria Raoultella ornithinolytica and Ensifer adhaerens. Biotechnol Rep 16:12-17. doi: 10.1016/j.btre.2017.10.001

Huang XF, Santhanam N, Badri DV, Hunter 
WJ, Manter DK, Decker SR (2013) Isolation and characterization of lignindegrading bacteria from rainforest soils. Biotechnol Bioeng 110:16161626. doi: 10.1002/bit.24833

Jurado M, Martínez AT, Martínez MJ, Saparrat MCN (2011) Application of white-rot fungi in transformation, detoxification, or revalorization of agriculture wastes: Role of laccase in the processes. Compr Biotechnol 6:595-603. doi: 10.1016/B978-0-08088504-9.00398-6

Khitrin KS, Fuks SL, Khitrin SV, Kazienkov SA, Meteleva DS (2012) Lignin utilization options and methods. Russ $J$ Gen Chem 82:977-984. doi: 10.1134/S1070363212

Lee JW, Kim HY, Koo BW, Choi DH, Kwon M, Choi IG (2008) Enzymatic saccharification of biologically pretreated Pinus densiflora using enzymes from brown rot fungi. J Biosci Bioeng 106:162-167. doi: 10.1263/jbb.106.162

Liew PWY, Jong BC, Goh CM, Ahmad M (2009) Bacterial diversity associated with empty oil palm fruit bunch compost as revealed by cultivationindependent analyses of PCRamplified 16S rRNA genes. J Gen Appl Microbiol 55:233-240. doi: 10.2323/jgam.55.233

López MJ, Guisado G, Vargas-Garcia MC, Suárez-Estrella F, Moreno J (2006) Decolorization of industrial dyes by ligninolytic microorganisms isolated from composting environment. Enzyme Microb Technol 40:42-45. doi: 10.1016/j.enzmictec.2005.10.035

Prenafeta-Boldú FX, de Hoog GS, Summerbell RC (2018) Fungal communities in hydrocarbon degradation. In: McGenity TJ (ed) Microbial communities utilizing hydrocarbons and lipids: Members, metagenomics and ecophysiology, handbook of hydrocarbon and lipid microbiology, Springer, Cham, pp 136 . doi: 10.1007/978-3-319-600635 8-2

Riley R, Salamov AA, Brown W, Nagy LG, Floudas D, Held BW, Levasseur A, Lombard V, Morin E, Lindquist EA, Sun $H$, Labutti KM, Jabbour $D$, Luo $H$,
Baker SE, Antonio G, Walton JD, Blanchette RA, Martin F, Cullen D, Hibbett DS, Riley R, Salamov AA, Brown DW, Nagy LG, Floudas D, Held BW (2014) Extensive sampling of basidiomycete genomes demonstrates inadequacy of the white-rot/brown-rot paradigm for wood decay fungi. Proc Natl Acad Sci 111:9923-9928. doi: 10.1073/pnas. 1418116111

Rodríguez-Couto S. (2017) Industrial an environmental applications of white-rot fungi. Mycosphere 8:456-466. doi: $10.5943 /$ mycosphere/8/3/7

Rosli NS, Harun S, Jahim JM, Othamanimia R, (2017) Chemical and physical characterization of oil palm empty fruit bunch. Malays J Anal Sci 21:188-196. doi: http://dx.doi.org/10.17576/mjas2017-2101-22

Ruiz-Dueñas FJ, Martínez AT (2009) Microbial degradation of lignin: How a bulky recalcitrant polymer is efficiently recycled in nature and how we can take advantage of this. Microb Biotechnol 2:164-177. doi: 10.1111/j.1751-7915.2008.00078.x

Valencia PE, Meitiniarti VI (2017) Isolasi dan karakterisasi jamur ligninolitik serta perbandingan kemampuannya dalam biodelignifikasi. Scripta Biologica 4:171-175. doi: 10.20884/1.sb.2017.4.3.449

Widiastuti H, Prakoso HT, Suharyanto, Siswanto (2015) Optimasi pengomposan tandan kosong kelapa sawit menggunakan dekomposer bakteri lignoselulolitik skala komersial. Menara Perkebunan 83:60-69. doi: 10.22302/iribb.jur.mp.v83i2.2

Woo HL, Hazen TC, Simmons BA, DeAngelis KM (2014) Enzyme activities of aerobic lignocellulolytic bacteria isolated from wet tropical forest soils. Syst Appl Microbiol 37:6067. doi: 10.1016/j.syapm.2013.10.001

Xu JZ, Zhang JL, Hu KH, Zhang WG (2013) The relationship between lignin peroxidase and manganese peroxidase production capacities and cultivation periods of mushrooms. Microb Biotechnol 6:241-247. doi: 10.1111/j.1751-7915.2012.00365.x

Yang CX, Wang T, Gao LN, Yin HJ, Lü X (2017) Isolation, identification and 
characterization of lignin-degrading bacteria from Qinling, China. J Appl Microbiol 123:1447-1460. doi: 10.1111/jam.13562

Zainudin MHM, Hassan MA, Md Shah UK, Abdullah N, Tokura M, Yasueda $\mathrm{H}$, Shirai Y, Sakai K, Baharuddin AS (2014) Bacterial community structure and biochemical changes associated with composting of lignocellulosic oil palm empty fruit bunch. BioResour 9:316-335. doi: 10.15376/biores.9.1.316-335

Zhang J, Presley GN, Hammel KE, Ryu J, Menke JR, Figueroa M, Hu D (2016) Localizing gene regulation reveals a staggered wood decay mechanism for the brown rot fungus Postia placenta. Proc Natl Acad Sci 113:10968-10973. doi: 10.1073/pnas. 1608454113 